\title{
Climate Smart Agriculture Practices in Semi-arid Northern Ghana: Implications for Sustainable Livelihoods
}

\author{
Rahinatu Sidiki Alare ${ }^{1}$, Erasmus Henaku Owusu ${ }^{2}$ \& Kwadwo Owusu ${ }^{3}$ \\ ${ }^{1}$ Institute for Environment and Sanitation Studies, University of Ghana, Ghana \\ ${ }^{2}$ Centre for Climate Change and Sustainability Studies, University of Ghana, Ghana \\ ${ }^{3}$ Department of Geography and Resource Development, University of Ghana, Ghana \\ Correspondence: Rahinatu Sidiki Alare, Institute for Environment and Sanitation Studies, University of Ghana, \\ Ghana. E-mail: alarerahina@gmail.com
}

Received: April 19, 2018

doi:10.5539/jsd.v11n5p57
Accepted: June 16, $2018 \quad$ Online Published: September 18, 2018

URL: https://doi.org/10.5539/jsd.v11n5p57

\begin{abstract}
Achieving food security and livelihood development among vulnerable households in the semi-arid regions is challenged by water scarcity and climate change. To alleviate the challenges of water scarcity and climate change impacts, farmers are adopting different climate smart agriculture (CSA) practices. However, there is limited knowledge on the contribution of CSA practices to livelihoods of farmers in semi-arid northern Ghana. Therefore, this paper explored CSA practices adopted by smallholder farmers and assessed the contribution of dry season farming to livelihoods in rural semi-arid Ghana. Using data from 100 households, farm income, household food security and subjective wellbeing (SWB) were compared between dry season farmers and non-dry season ones. The findings showed that socio-economic factors hindered the utilisation of practices with high start-up cost such as rain water harvesting. Farmers also adopted other practices based on the benefits, ease of use and geographical context. Comparing dry season farmers and non-dry season ones, the results showed that dry season farming had great potentials of improving income, food security $(66 \%)$ and wellbeing $(\mathrm{P}>0.01)$ of rural households in semi-arid Ghana. However, adopting CSA practices only without instituting programmes to address other socio-economic challenges faced by smallholder farmers will yield minimal impacts. Complementing CSA initiatives with poverty alleviation programmes will effectively contribute to improved livelihoods in resource poor communities.
\end{abstract}

Keywords: CSA (Climate-Smart Agriculture), smallholder farmers, wellbeing and, sustainable livelihood

\section{Introduction}

Smallholder farming dominates the agricultural landscape in Sub-Saharan Africa (SSA) and mostly operates on less than 2 ha in total landholdings (Lowder et al., 2014). While these little agriculture realities provides food security and income for many households, it faces the challenge of increasing production to ensure food security for the growing population alongside with preserving its environment and natural resource base (FAO, 2013). These goals are further exacerbated by climate change and variability interacting with pre-existing socio-economic, cultural and political inequalities to shape vulnerability. Yet, population growth and increasing consumption of high calorie and meat-intensive diets are expected to double human food demand by 2050 (Tilman et al., 2011). Smallholder farmers will play a critical role in meeting this target.

Increasing productivity to achieve food security is expected to entail a significant escalation in emissions from the agricultural sector especially in developing countries (Long et al., 2016). Therefore, achieving the needed levels of productivity with lower emissions of GHGs will require concerted efforts to maximize synergies and minimize trade-offs between productivity and mitigation while at the same time ensuring that production systems are resilient to the changing climate. The promotion of Climate-Smart Agriculture (CSA) by the Food and Agriculture Organisation (FAO) and Consultative Group on International Agricultural Research (CGIAR) is an initiative in this regard. CSA aims at fostering development and entails implementation of agriculture innovations directed at: (1) increasing agricultural productivity to support incomes, food security and development; (2) improving adaptive capacity at multiple levels (farm to nation) and (3) decreasing greenhouse gas emissions and increasing carbon sinks (Campbell et al., 2014; Zougmoré et al., 2016). CSA embodies existing strategies on sustainable land management (SLM) practices such as, among others, conservative agriculture, agroforestry, integrated livestock 
management, watershed management that promotes the triple wins of increasing productivity, enhancing adaptation and mitigation (Branca et al., 2011).

In West Africa, climate change is already impacting on individuals and national economies due to over reliance on sensitive sectors. For example, since 1960, it is estimated that Ghana has experienced a degree rise in temperature and reduction in rainfall in all agro-ecological zones (EPA, 2015). However, future climate projections in West Africa indicate increases in temperature (until 2100) with uncertainties surrounding precipitation (Riede et al., 2016). Although climate modelling is important for adaptation planning, addressing the variability experienced year to year and within each growing season is of more priority in Africa since it has implication on food security and livelihoods (Yaro, 2013).

In Northern Ghana, climate change and variability manifesting as dry spells, droughts and "false starts" of rainfall pose threats to crop productivity especially at the critical stages of plant development (Mawunya \& Adiku, 2013). Thus, achieving food security and livelihood development among vulnerable households is constrained by water scarcity. For instance, Rademacher-schulz (2014) established that a decrease in rainfall patterns and dry spells have caused declines in crop yields in Northern Ghana. Bawayelaazaa et al. (2016) also found that, precipitation and temperature significantly impacted on the net revenue per hectare of maize and sorghum in Northern Ghana using estimates from Ricardian regression models. Using climate data and cultivated land sizes of maize, sorghum and millet, Ahmed et al (2016) demonstrated that, climate variability and socio-economic factors influenced productivity in semi-arid Ghana. Northern Ghana has also experienced several droughts and few floods (Lolig et al., 2014). Key among the devastating impacts experienced, was the 2007 floods which destroyed farmlands, infrastructure and livelihoods (Yaro, 2013). With growing impacts of climate variability experienced in these areas, farmers have resorted to coping strategies such as migration, crop and livelihood diversification, livestock rearing, remittances, membership in farmer-based organisation and other social networks (Ahmed et al., 2016). Additionally, the promotion of sustainable land management practices which are examples of CSA practices (Branca et al., 2011) have influenced paradigm shifts from traditional practices. This has also necessitated the development of CSA strategies and policies at different levels of governance (Zougmoré et al., 2016). It is therefore highly imperative to sustain livelihoods which are predominantly agrarian in these regions.

In response to the climatic conditions of semi-arid regions, irrigation and agricultural water management (AWM) have been proposed as the way forward to improving food security and incomes of smallholder farmers (Douxchamps et al., 2015). Semi-arid Ghana is characterised by a unimodal rainfall pattern. During the dry season which ranges between November and May, communities which have water bodies resort to minor irrigation farming to compliment household food security needs. This practice is commonly or locally referred to as dry season farming (hereafter, referred to as dry season farming). However, while there are documented success stories on irrigation interventions, some smallholder farmers still face the challenge of increasing productivity and income (Barron \& Noel, 2011). Douxchamps et al. (2015) also raises concerns about the inability of some studies to quantify the impacts of AWM strategies on livelihoods although these strategies are purported to improve livelihoods. It is against this backdrop that this paper seeks to assess the contribution of dry season farming, as a CSA strategy, on smallholder farmers' livelihoods. CSA can only make effective contribution to local adaptation, if it is explored in different places and context-specific cases (Peterson, 2014). Therefore, the objective of this study is to understand the dynamics of CSA strategies adopted by smallholder farmers in semi-arid areas of Ghana in terms of its implication on farmers' livelihoods. Specifically, the paper i) documented local CSA strategies adopted by farmers; ii) assessed the contribution of dry season farming to household food security and income and iii) explored bottlenecks to effective adoption of dry season farming.

\section{Methods}

\subsection{Study Area}

The analysis was carried out in two communities, namely Anafobiisi and Gowrie-Kunkua in the Bongo District $\left(10^{\circ} 30^{\prime}-11^{\circ} \mathrm{N} ; 0^{\circ}-1^{\circ} \mathrm{W}\right)$ of the Upper East Region of Ghana, located in the Sudan Savannah agro-ecological zone. The district is bordered to the north by Burkina Faso, to the east by Nabdam District, to the west by Kasena-Nankana District and to the south by Bolgatanga Municipality (Figure 1). The land is relatively flat with a few hills to the east and southeast. The district covers a total land area of $459.5 \mathrm{~km}^{2}$ (GSS, 2014a), The region has a uni-modal rainfall pattern with annual rainfall totals ranging between 700 and $1200 \mathrm{~mm}$ and a mean monthly temperature of $21^{\circ} \mathrm{C}$ (Blench, 2006). Mixed farming is commonly practiced in the district. The main crops include sorghum (Sorghum), millet (Pennisetum glaucum), roselle (Hibiscus sabdariffa), okra (Abelmoschus esculentus), cowpea (Vigna unguiculata) and peanuts (Arachis hypogaea).

Many livelihoods (72.6\%) in the Bongo District are dependent on agriculture (GSS, 2014b) which is 
predominantly rain fed and threatened by both climatic and non-climatic stressors (Antwi-Agyei et al., 2012). Historical perspectives of vulnerabilities of Northern Ghana have been attributable to unfavourable climate, poverty, food security, water scarcity, unsustainable farming practices and post-independence political neglect (Nyantakyi-Frimpong \& Bezner-Kerr, 2015). Currently, these multi-stressors are further heightened by the influences of climate variability and change with implications on household food security and wellbeing (Yiran \& Stringer, 2016).

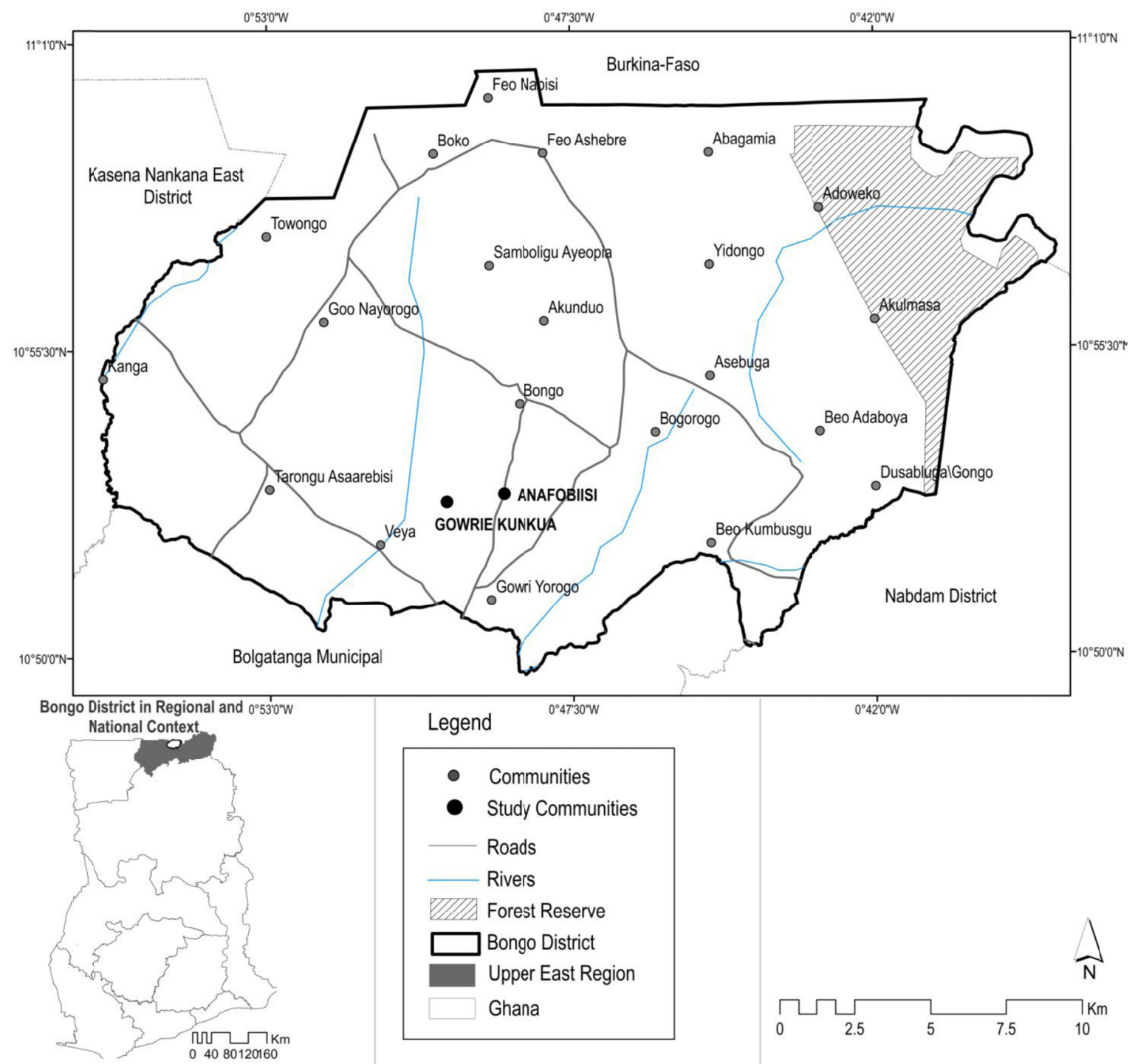

Figure 1. Location of the study sites

\subsection{Data Collection}

A mixed method approach was used in this study consisting of a household survey ( $\mathrm{n}=100$ households) and focus group discussions, FGDs $(n=4)$ in two communities (Anafobiisi and Gowrie-Kunkua) in the Bongo District. Participants were selected using both random and snowball sampling (Latham, 2007). Anafobiisi community had no agro-pastoral reservoir to practice dry season farming, therefore, respondents were randomly selected. In contrast to Anafobiisi, respondents from Gowrie-Kunkua community were surveyed using the snowball sampling since they had a reservoir and practiced both rainy and dry season farming

The semi-structured questionnaire was used to collect the socio-economic data of respondents, awareness and use of farming practices adopted and livelihood outcomes with indicators such as income, food security and subjective wellbeing (SWB). The selected CSA strategies included: household tree planting, manure application, crop rotation, mulching, intercropping, manure management, improved forages, improved livestock breeds, 
improved crop varieties, dry season farming, minimal tillage, stone bunds, residue management, rainwater harvesting and contour ploughing (Branca et al., 2011; Peterson, 2014 ). In this study, adoption was defined as the use of the practice at least in the last farming season. Information was also collected to establish whether the awareness of a practice influenced its adoption.

Income sources of rural households are increasingly gaining recognition in literature for being underreported in most scholarships (Davis et al., 2017; Tambo \& Wünscher, 2017). While this research acknowledges this concern, the data collection focused solely on the contribution of CSA practices to household finances. Some case studies (eg. Makate et al., 2016) have shown increases in household income through adopting some CSA practices. Therefore, revenue sources and measurements were made from the sale of crops and livestock only in the last 12 months before data collection.

Food security data was collected using food consumption score (FCS) and household food insecurity assessment score (HFIAS) approach. FCS is a composite one, based on dietary diversity, frequency and relative nutrition of different diet groups by a household during the last seven days before the survey WFP (2008). The HFIAS captures household behaviour as a way of indicating insufficient quality and quantity as well as anxiety and uncertainty over food supply. The HFIAS score was computed following Coates \& Bilinsky (2007). For SWB, information was collected on life satisfaction, happiness, worthwhileness and anxiousness of respondents with respect to farming activities. Questions were framed (see table 1) to address the three categories of measures (evaluation, experience and eudemonic) underpinning SWB and a Likert scale of 1-4 (1= not at all, 2= somewhat, $3=$ moderately and $4=$ very) was used to assess the questions.

The FGDs sessions were held separately for males and females (8-10 in a group) in each community. The FGDs focused on farming practices, livelihood outcomes derived from farming activities, and the challenges constraining the effective adoption of dry season farming as all other practices were common to the two communities with the exception of dry season farming. These gave more insights to the benefits and challenges associated with the practice.

\subsection{Data Analysis}

The survey data was analysed using descriptive and inferential statistics in Statistical Package for Social Science, SPSS version 21 and data presented as frequencies and means. Significance test was also analysed using Wilcoxon non-parametric, Spearman rho correlation and Mann-Whitney U test due to the skewness of the variables in a normality test. Specifically, descriptive statistics were used to summarise the socio-economic data and the percentages of households who were aware and using the CSA practices in the communities. This analysis was also used to present the distribution of income and household dietary diversity scores as well as the response rate of the various dimension of wellbeing. The Mann-Whitney U test was used to compare statistical differences between groups (non-dry season farmers and dry season farmers) of each dimension of wellbeing. The spearman's rho correlation was used to assess associations between livelihood outcomes (income and food security) and the various dimensions of subjective wellbeing. To compare food security patterns between the users and non-users of dry season farming, a two-sample Wilcoxon non-parametric test was performed. Wilcoxon sum rank test compares the underlying distribution of a response variable between two independent variable (Megersa et al., 2014).

\section{Results}

\subsection{Socio-Economic Data}

The mean ages of respondents were 46.9 years in both communities. $66 \%$ of the farmers were males while the remaining $34 \%$ were females. A greater segment (73\%) had no formal education and the average household sizes in both communities were 8.2. The average compound farm size was about 2.3 acres ( 0.93 hectares) and irrigated or dry season farmlands were 0.49 acres $(0.2$ hectares). As indicated earlier, Anafobiisi community was not involved in dry season farming, because they had no reservoir in the community. In both communities, a few farmers were involved in additional livelihoods such as petty trading and artisanal work to supplement income. All households reared at least poultry, livestock or both. 
Table 1. Socio-economic data

\begin{tabular}{lll}
\hline Variable & Anafobiisi & Gowrie-Kunkua \\
\hline Mean ages of respondents & 48.4 & 45.4 \\
Male headed households & 84 & 92 \\
Female headed households & 16 & 8 \\
\% of Respondents who never attended school & 78 & 88 \\
Mean household size & 7.7 & 8.6 \\
Mean compound farms (acres) & 2.2 & 2.4 \\
Mean irrigated farms (acres) & 0 & 0.98 \\
\hline
\end{tabular}

\subsection{Locally-Adopted CSA Practices}

As it can be observed from figure 2, many of the respondents were already aware of the practices shown to them. Despite the awareness, the most adopted CSA were intercropping (100\%), minimal tillage $(100 \%)$, residue management (100\%), manure application (96\%), contour ploughing (88\%) and crop rotation (86\%). However, the least adopted practices were manure management $(11 \%)$ and rain water harvesting $(0 \%)$.

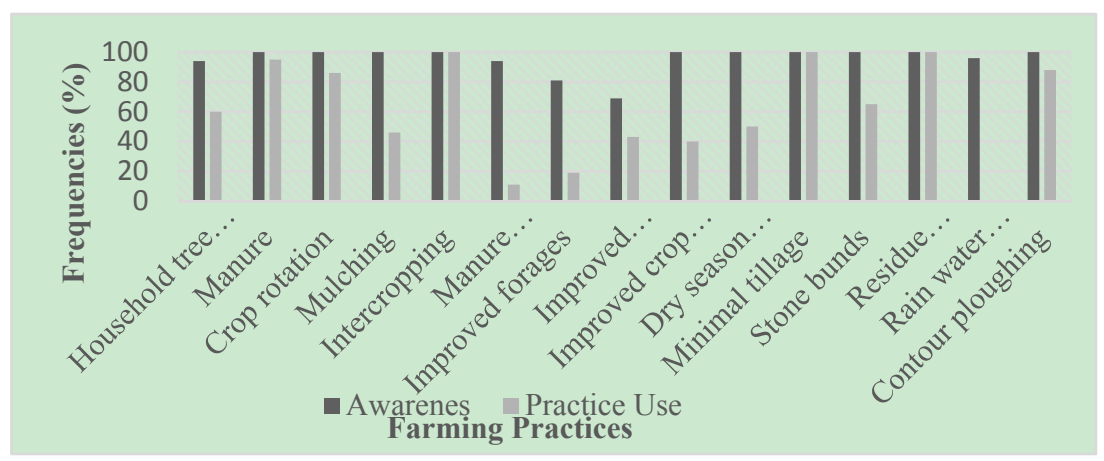

Figure 2. CSA awareness and adoption rates by households

\subsection{Challenges Associated with CSA Practices}

As summarised in table 3, farmers in both communities noted that for the least adopted practices such as household tree planting, untimely access to tree seedlings during the rainy seasons caused young plants to wilt in the dry season. Mulch was also barely used on crops with the exception of vegetables in their nursery stages. Thus, this practice was mostly adopted by the dry season farmers who cultivate vegetables. Insufficient residues as a result of being scorched by high temperatures and its competing use prevented most farmers from widely practicing mulching. Other strategies such as manure management, rain water harvesting, improved livestock breeds and crop varieties hinged on finances and insufficient information. 
Table 2. Challenges associated with the adoption of some CSA practices

\begin{tabular}{|c|c|}
\hline CSA Practices & Challenges \\
\hline Household tree planting & $\begin{array}{l}\text { - Timing of tree planting exercises (usually tree seedling are } \\
\text { provided after the rainy season, posing challenges with access to } \\
\text { water for watering planting). } \\
\text { - Rocky land obstructs access to soil nutrients and water by plant } \\
\text { roots. } \\
\text { - Dry spells wilts plants. } \\
\text { - Livestock graze on young trees. }\end{array}$ \\
\hline Mulching & $\begin{array}{l}\text { - Seasonal variations such as low humidity and high temperatures } \\
\text { scorch grasses and crop residues. } \\
\text { - } \quad \text { Competing use for feeding livestock, farming and for fuel. } \\
\text { - } \quad \text { Low productivity in crops resulting in less crop residue. }\end{array}$ \\
\hline Manure management & $\begin{array}{l}\text { - Cost associated with constructing a structure to contain dung and } \\
\text { pellets from livestock. }\end{array}$ \\
\hline Improved forages & - Insufficient information. \\
\hline Improved livestock/poultry breed & $\begin{array}{l}\text { - } \text { Prone to constant pest and disease attacks. } \\
\text { - } \quad \text { Cost associated with purchasing new breeds and drugs. } \\
\text { - } \quad \text { Insufficient information on the available breeds in the market. }\end{array}$ \\
\hline Improved crop varieties & - Cost associated with purchasing new crop varieties. \\
\hline Rain water harvesting & - Cost in constructing reservoirs for collecting surface runoff water. \\
\hline
\end{tabular}

\subsection{CSA Practices and Household Income}

The results of the study indicated that most of the farm production were not sold but employed for subsistence. Farmers only sold their crops if they had to attend to pressing issues. As reported in figure (3),the mean annual income from Anafobiisi and Gowrie-Kunkua communities were GHC 13.4 and GH 174.6 for the sale of crops, respectively. The difference in earnings could be attributed to the adoption of dry season farming by Gowrie-Kunkua community who farmed throughout the year. Despite differences in income from the sale of crops, in both communities, livestock made major contributions (GHC 563.16) to household earnings averagely, compared to crops. Livestock was considered an asset.

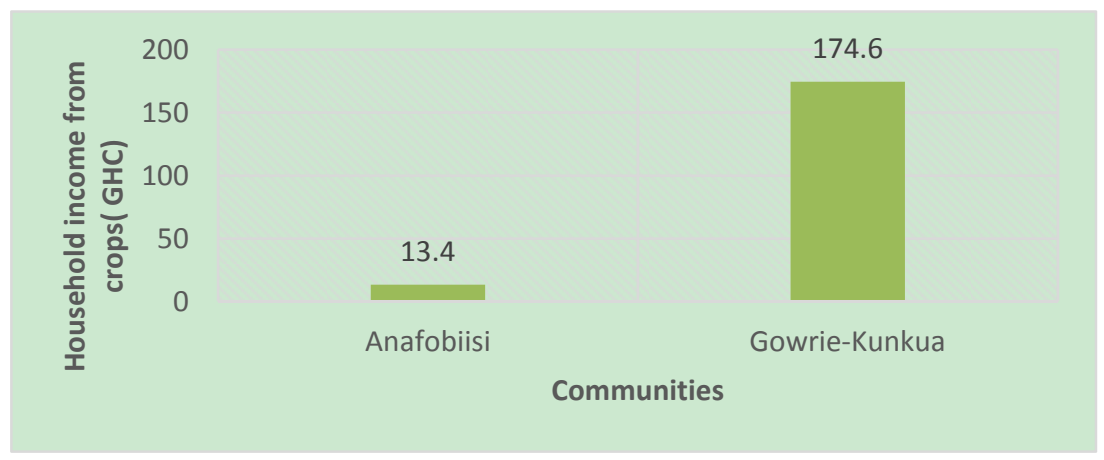

Figure 3. Household income from crop sales

\subsection{Food Security}

As it can be observed in figure 4, the results from the weekly dietary diversity score (DDS) showed that staple crops such as maize (Zea mays), millet (Pennisetum glaucum) and sorghum (Sorghum) dominated in the diets of most households and it is often served with vegetable sauce. Condiments such as salt, spices and fish powder are 
also added to sauce for a better a taste in many households. Sugar was considered here as a condiment because respondents consumed it only when drinking a beverage. The terciles shows the percentages of respondents and the diet consumed in the lower, medium and higher interquartile ranges. Pulses $(47 \%)$, vegetables (48\%), fruits (48\%) meat (45\%), condiments (46\%) and oils (49\%) were all consumed by farmers in the upper terciles. However, staples had equal distributions across the terciles since it was consumed each day by all respondents across the week. In general, most of the respondents in all the three terciles had diversified diets ranging from 3 to 7 times in a week. Using the wilcoxon non-parametric test, significant differences in the mean rank of food consumption score were observed between dry season farmers and non-dry season farmers $(z=-2.29, p=0.03)$ with indications that dry season farmers had more diversed diets than the non-dry season farmers.

While households in both communities showed diverse diets, an analysis of the household behaviours as a measure of food insecurity indicated that most non-dry season farmers in Anafobiisi community (64\%) were severly food insecure. $34 \%$ were moderately food insecure with $2 \%$ being mildly food insecure. In contrast to Anafobiisi community, most dry season farmers (66\%) in Gowrie-Kunkua were moderately food insecure, $22 \%$ and $12 \%$ being severely and mildly food insecure respectively. Comparatively, dry season farmers were more food secured than those who cultivated only during the rainy season (Figure 5).

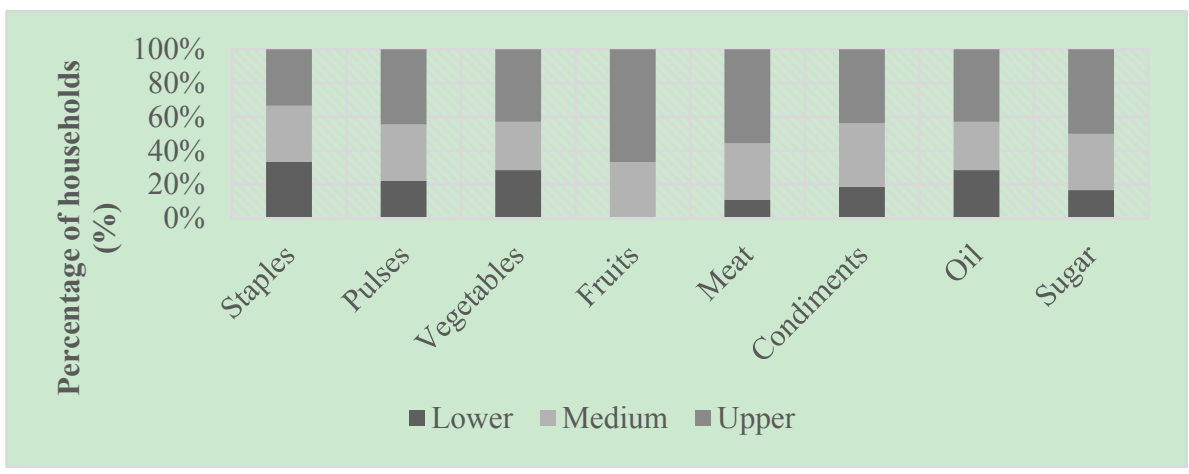

Figure 4. Household dietary diversity score based on different quartiles

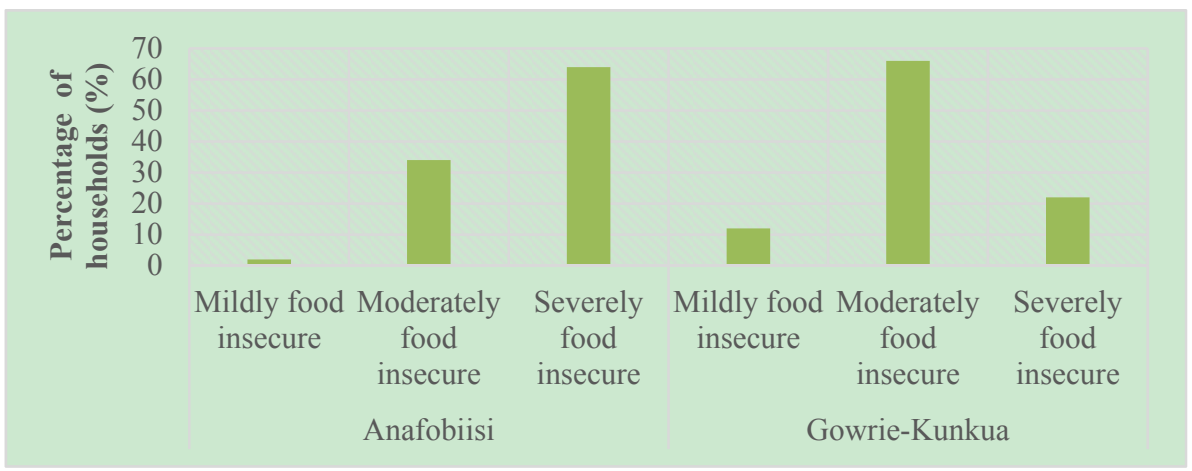

Figure 5. Proportion of households based on HFIAS

\subsection{Subjective Wellbeing}

We compared non-dry season and dry season farmers across four dimensions of subjective wellbeing (Table 4). Most households in both communities were somewhat satisfied (49\%), worthwhile (55\%), happy (51\%)and anxious (45\%) with varied responses in the rest of the levels of the dimensions. However, using a Mann-Whitney U-test, significant differences were observed between non-dry season farmers and dry season farmers. The dry season farmers scored higher mean ranks than the non-dry season farmers. The distribution between non and dry season farmers showed that those who farmed in both seasons felt better off $(\mathrm{P}<0.01)$ than the dry season farmers for measures of satisfaction, happiness, anxiousness and worthwhileness $(\mathrm{P}<0.05)$.

Findings from spearman's rho correlation indicated that, income from crops strongly associated with satisfaction $(\mathrm{P}<0.05)$ and with happiness $(\mathrm{P}<0.01)$. No relationship was observed for income from livestock and wellbeing. However, strong linkages were observed for food consumption score and satisfaction, worthliness and happiness. 
Measures of HFIAS and the four dimensions of wellbeing showed stronger associations $(\mathrm{P}<0.01)$ (Table 5).

Table 3. Comparison between different groups and their subjective wellbeing

\begin{tabular}{llll}
\hline \multirow{2}{*}{ Dimensions of wellbeing } & \multicolumn{2}{c}{ Mean ranks } & P-values \\
\cline { 2 - 3 } & Dry season farmers & Non-dry season farmers & \\
\hline Satisfaction & 40.72 & 60.28 & $0.000^{* *}$ \\
Worthwhileness & 43.87 & 57.13 & $0.011^{*}$ \\
Happiness & 40.39 & 60.61 & $0.000^{* *}$ \\
Anxiousness & 43.05 & 57.95 & $0.006^{*}$ \\
\hline p values are based on Mann Whitney U test as the averages are not normally distributed
\end{tabular}

Note: all $\mathrm{p}$ values are based on Mann Whitney $\mathrm{U}$ test as the averages are not normally distributed

$* *$ at $1 \%$ level of significance and $* 5 \%$ level of significance

Table 4. Associations between livelihood outcomes and subjective wellbeing

\begin{tabular}{lllll}
\hline \multirow{2}{*}{ Livelihood Outcomes } & \multicolumn{3}{l}{ Dimensions $(\boldsymbol{p}$-value) } \\
\cline { 2 - 5 } & Satisfaction & Worthwhileness & Happiness & Anxiousness \\
\hline Income from crop sales & $0.024^{*}$ & 0.057 & $0.008^{*}$ & 0.129 \\
Income from livestock sales & 0.575 & 0.542 & 0.874 & 0.466 \\
FCS & $0.000^{* *}$ & $0.015^{*}$ & $0.013^{*}$ & 0.167 \\
HFIAS & $0.000^{* *}$ & $0.000^{* *}$ & $0.000^{* *}$ & $0.002^{* *}$ \\
\hline
\end{tabular}

** at $1 \%$ level of significance and * 5\% level of significance

\subsection{Bottlenecks to Effective Dry Season Farming}

According to the focus group discussions, while available water for farming is key to promoting food security in the semi-arid areas, communities such as Anafobiisi and Gowrie-Kunkua were constrained by that. Lack of reservoirs were the major bottleneck in Anafobiisi. However, Gowrie-Kunkua noted broken canals, increased charges of water supply to farms. The geography ( $40 \%$ of rock cover) of Anafobiisi also impeded successful crop productivity, despite efforts invested in farming. In both communities, infertile soils, rudimentary technologies, land fragmentation from increasing population, financial constraints and seasonal migration were discussed as the issues hindering successive adoption of dry season farming (Figure 6).

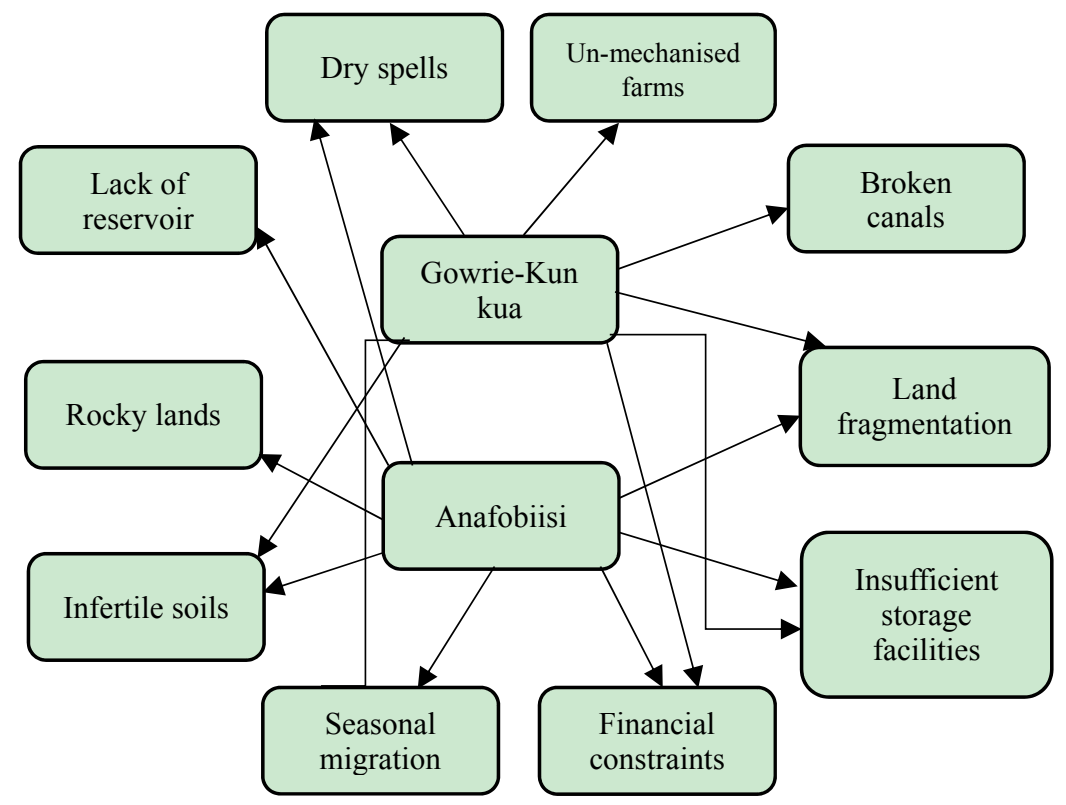

Figure 6. Bottlenecks to dry season farming 


\section{Discussions}

\subsection{Local CSA Practices Adopted by Smallholder Farmers}

In the study area local CSA practices have been promoted and adopted by farmers. Widely-adopted practices included intercropping, minimal tillage, residue management, manure application, contour ploughing and crop rotation. This is consistent with the findings of other studies (Branca et al., 2011), confirming that the adoption of these practices are associated with increasing productivity for household food security and soil fertility enhancement. While minimal tillage promotes less soil disturbance, evaporation and enhances soil structure (Johansen et al., 2012), most farmers did not like the practice but adopted it because they could not afford to purchase tractors and carts to plough land. Also, the few available tractors were not enough for those who could afford to rent one. A farmer from Gowrie-Kunkua described the situation by noting that;

"... I am ploughing my land with a hoe because there are no enough tractors and carts for rent. There is so much pressure on the available one and if I have to wait till it gets to my turn, the rains would go and my seeds will not germinate. Ploughing with the hoe is tiresome and I do get body aches, I prefer using a cart or the tractor..."

A 46-year-old farmer from Gowrie-Kunkua

As reported by other studies (eg. Matusso et al., 2012), intercropping was widely adopted in the area because it promotes both diversification of crops and offsets losses. The crops often intercropped included millet (Pennisetum glaucum), guinea corn (Sorghum), and vegetables such as roselle (Hibiscus sabdariffa), pepper (Capsicum sp.), tomatoes (Solanum lycopersicum) and okra (Abelmoschus esculentus). From the focus group discussions, soil fertility management such asd residue management and manure management were widely adopted also because of ease of acess and sensitization on the effects of burning crop residues on farmlands by some Non-governmental organisations (NGOs). Most respondents indicated that cow dung, corn stalks, groundnut haulms and vines of other vegetables were left on farm lands after harvesting to decay and increase soil nutrients instead of the normal practice of burning. As reported by other studies (Bationo \& Mokwunye, 1991; Valbuena et al., 2014) competing use of crop and animal residues for livestock feed and other off- farm activities constrained the actualisation of the benefits of this practice in these areas. Additionally, the support of traditional authorities in promoting environmental management also influenced uptake of these practices. For instance, Anafobiisi community had a 'tree chief' whose duty was to ensure the protection and preservation of woodlots. Therefore, any community member who defied any of the rules by cutting down a tree or indiscriminately burn a bush without proper consultation was asked to pay a fine. These fines ranged between an amount of GHC100- GHC 200, a query or the provision of tree seedlings for replanting.

Livestock rearing was however perceived as an asset as it contributed extensively in buying household groceries during the hunger gap period, financing farmers' wards education and other social functions. It was therefore not suprising to have livestock and poultry rearing generate more income in both communities compared to income from food crops. Most farmers preferred the local breeds to the foreign livestock and poultry breeds because of the cost associated in keeping them. The foreign livestock and poultry were prone to pest and disease attack and worsened by the cost associated in accessing the services of a vertinary doctors and the vacinnes for these breeds. Consistent with other studies (Adam et al. 2017), the findings of the present paper also revealed that water scarcity, especially in the dry season and the free range system of keeping livestock and poultry, exposed them to theft and insanitary conditions which made them prone to pest and diseases.

While awareness of a practice may influence its adoption, it did not necessarily translate into adoption for some practices in these communities. The implementation of these practices were embedded in socio-economic challenges. For instance, financial constraints accounted for the low adoption rates in rain water harvesting, manure management, improved livestock breeds and crop varieties because it required major investments. For example, most respondents could not afford to build a structure to contain animal droppings, or a reservoir to collect rain water.

\subsection{Household Income and Food Security}

The results showed that, despite adopting most of the CSA practices, crop production was to some extent sufficient for subsistence only. This study contradicts findings from other studies (Branca et al., 2011; Makate et al., 2016) who experienced increases in crop yields by adopting improved agronomic practices. The incongruity is as result of the small land holding sizes, rocky lands, infertile soils and others indicated in figure 6. Prolonged hunger gaps were often experienced between April and July, which made selling crops not an option. Respondents who farmed in both rainy and dry seasons had more income from crops contributing to household income comapred to those who cultivated in the rainy season. There were also variations in financial levels among households in the same 
community. From the FGDs, these variations were associated with farm size, household size, crop productivity and quantity and type of livestock sold. Challenges associated with improving crop productivity were in line with challenges associated in adopting some CSA practices. Key among the challenges, especially in Anafobiisi community, was the dominance of rocks in landholdings coupled with increasing population growth reducing landholdings for agricultural activities. Intra seasonal shocks such as false starts in rainfall also affected crop production in both communities as explained by one female household head from Anafobiisi:

“...My farmland is dominated by rocks and the erratic nature of the rains prevents my crops from thriving. There are instances I thought it was the onset of the rains and I decided to start planting, however, the rains stopped and my crops withered on the rocks. I had to beg for seeds from neighbours to re-plant when the rains came again."

\section{A 40-year-old widow from Anafobiisi}

Despite dry season farming or irrigation having great potentials in improving livelihoods of farmers, this study recorded minimal contributions because of the embedness of pre-existing socio-economics factors in Gowrie-Kunkua community. Nonetheless, comparing income and food insecurity assessment score in both communities showed that Gowrie-Kunkua was better off than Anafobiisi community. This is attributed to the presence of a water reservoir to support farming activities throughout the year. Ineffective adoption of dry season farming was also as a result of being charged GHC 60 per acre by the Irrigation Company of Upper Regions (ICOUR) for access to water for farming which could not be afforded by these farmers. These monies were charged to fix broken canals and maintenance of irrigation facilities. These have resulted in trepidations raised on the implementation and management of small scale irrigation schemes ( Douxchamps et al. (2015). Thus, among other recommendations for enhancing small scale irrigation schemes, Amede (2015) recommends the combination of strategies and institutional capacity which includes (i) an improved design that considers structural and infrastructural designs, (ii) introduction of high yielding, water efficient and high value crops and (iii) enhancing innovative capacity of water users association and establishment of reliable market linkages to suppport these schemes.

In the case of Anafobiisi community, most households were severely food insecured. As explained earlier, dry spells, rocky lands, financial constraints and land fragmentation hindered effective farming activities. This was how a 31 year old man explained the situation on land fragmentation:

“...look at my small plot. I had this small piece of land after my dad shared his plot among me and my brothers. What I grow on this land cannot sustain me till the next farming season, it is only to have a taste and not for consumption..."

A 31-year-old man from Anafobiisi

In both communities, apart from livelihood diversification, most households adopted seasonal migration to the Northern Region and Southern Ghana as a coping strategy to dwindling food stocks. This finding also supports the results of other studies who noted the contributions of seasonal migration to household food security (Ahmed et al., 2016; Rademacher-schulz et al., 2014). With recent debates on climate change as a driver of migration, findings of this paper validates with a recent study in northern Ghana (Ahmed et al., 2016) which indicates that migration is induced by the inextricable linkages between climatic and non-climatic stressors.

\subsection{CSA and Subjective Wellbeing}

The findings indicated varied responses on the likert scale but most households were somewhat satisfied, happy, anxious or found their farming activities worthwhile. Significant differences also existed between dry season farmers and non-dry season ones in terms of the various dimensions of SWB. This is obvious from the results of income and food insecurity analysis when compared between the two communities. For most households in both communities, low productivity, long period of hunger gaps and financial constraints played a key role on how households felt. Although there were no associations between income from livestock and the other dimesions of SWB, a strong association was rather observed between income from crop sales and life satisfaction which is supports other findings (Dolan et al., 2011). Strong correlations were also observed between HFIAS, FCS and the four dimensions of SWB. This finding upholds with a study conducted to assess the association between needs and SWB (Tay \& Diener, 2011). Tay \& Diener (2011) found out that life satisfaction was met when a person: 1) had enough money to buy food; 2) had enough money for shelter and 3) did not go hungry. This is true also for this study as what mattered most in many households were not the material aspects of life but how to provide food for households and other basic needs of life.

Evidence from this study therefore shows that, CSA practices can only make effective contribution if it takes into consideration the geographical and the socio-economic context of the place of intervention. Adopting CSA 
practices only is not enough to promote food security and wellbeing, but complementing such activities with programmes to alleviate poverty will enhance incremental adaptation.

\section{Conclusion and Policy Recommendation}

The analysis of the livelihood outcome of farmers indicates that dry season farmers were better off than the ones who cultivated only in rainy season in terms of generating income and providing food security for households. The low income, prevalence of food insecurity and low mean ranks scores in SWB experienced by non-dry season farmers could be attributed to the prolonged hungers gaps, absence of reservoirs for irrigation and low productivity in farms. Dry spells also threatened food production, especially in the rainy season in both communities. Additionally, the dry season farmers also experienced these shocks, but the presence of the reservoir and additional livelihood opportunities such as the livestock rearing cushioned them and made it less pronounced when compared to the non-dry season farmers.

Some of the CSA practices are not new but existing ones which have been adopted by farmers since time immemorial (eg. Mimimal tillage and intercropping). CSA can only make effective contribution if it takes into consideration the geographical, socio-economic and in some cases the cultural context of a place before promoting an intervention. Though Gowrie-Kunkua had access to water for dry season farming, financial constraints limited investments in farming activities. Using this study as an example, promoting CSA practices only without addressing the socio-economic challenges encountered by these communities may yield no impact. As mentioned earlier, poverty alleviation programmes involving social cash transfers such as the Livelihood Empowerment Against Poverty (LEAP) programme introduced by the Government of Ghana which aims at alleviating short term poverty and encouraging long term human development is a step in the right direction. However, without proper targeting of poor households and regular payments, it may not compliment CSA initiatives in these communities. Consequently, self help groups (SHGs) are also emerging among rurals farmers as a form of access to credit and labour to support livelihood activities. However, its contribution to CSA and sustainability is yet to be fully explored. CSA practices can therefore make an impact if it is integrated with other development interventions with effective institutional collaborations, especially in resource poor communities.

Additionally, the capacities of farmers need to be built through frequent extension services as well subsidising farm inputs for easy access. Allocation of additional farmlands to Anafobiisi community by the Department of Agriculture will enhance household food secuirty since most of their landholdings are dominated by rocks. For perpetuity of uptake of services which require funding, effective collaboration between government, private and civil society organisations can promote continuous uptake of such services (for example, improved crop varieties or livestock breeds, irrigation and rain water harvesting).

\section{Acknowledgement}

This research is funded by the Open Society Foundation through the Building Capacity for Climate Change Challenge (B4C) project in Ghana. The authors are grateful to the reviewers for their useful comments in enriching this work.

\section{References}

Adam, J. N., Freeman, C. K., \& Dassah, E. Z. (2017). Access to dry season water and small ruminants market integration in the Nadowli District of Upper West Region of Ghana, 9 (November), 262-269. https://doi.org/10.5897/JAERD2017.0913.

Ahmed, A., Lawson, E. T., Mensah, A., Gordon, C., \& Padgham, J. (2016a). Adaptation to climate change or non-climatic stressors in semi-arid regions? Evidence of gender differentiation in three agrarian districts of Ghana. Environmental Development, 20, 45-58. https://doi.org/10.1016/j.envdev.2016.08.002.

Ahmed, A., Lawson, E. T., Mensah, A., Gordon, C., \& Padgham, J. (2016b). Adaptation to climate change or non-climatic stressors in semi-arid regions? Evidence of gender differentiation in three agrarian districts of Ghana. Environmental Development, 20, 45-58. https://doi.org/10.1016/j.envdev.2016.08.002.

Al-hassan, R. M., \& Diao, X. (2007). Regional Disparities in Ghana: Policy Options and Public Investment (Ghana Strategy Support Program (GSSP) Background Paper No. GSSP 0002).

Amede, T. (2015). Technical and institutional attributes constraining the performance of small-scale irrigation in Ethiopia. Water Resources and Rural Development, 6, 78-91. https://doi.org/10.1016/j.wrr.2014.10.005.

Arslan, A., McCarthy, N., Lipper, L., Asfaw, S., \& Cattaneo, A. (2014). Adoption and intensity of adoption of conservation farming practices in Zambia. Agriculture, Ecosystems and Environment, 187, 72-86. https://doi.org/10.1016/j.agee.2013.08.017. 
Barron, J., \& Noel, S. (2011). Valuing soft components in agricultural water management interventions in meso-scale watersheds: A review and synthesis. Water Alternatives, 4(2), 145-154.

Bationo, A., \& Mokwunye, A. U. (1991). Role of manure and crop residue in alleviating soil fertility constraints to crop production: With special reference th the Sahelian and Soudanian zones of West Africa. Fertiliser Research, 29, 117-125.

Bawayelaazaa, Nyuor, A., Donkor, E., Aidoo, R., Saaka Buah, S., Naab, J., ... Zougmoré, R. (2016). Economic Impacts of Climate Change on Cereal Production: Implications for Sustainable Agriculture in Northern Ghana. Sustainability, 8(8), 724. https://doi.org/10.3390/su8080724.

Blench, R. (2006). Background Conditions in Upper East Region, Northern Ghana. Retrieved from www.rogerblench.info/.../Ghana/.../Blench UER working pap...

Branca, G., Mccarthy, N., Lipper, L., \& Jolejole, M. C. (2011). Climate Smart Agriculture: A Synthesis of Empirical Evidence of Food Security and Mitigation Benefits from Improved Cropland Management. Retrieved from http://www.fao.org/climatechange/29764-0aa5796a4fb093b6cfdf05558c6dd20bb.pdf.

Campbell, B. M., Thornton, P., Zougmoré, R., van Asten, P., \& Lipper, L. (2014). Sustainable intensification: What is its role in climate smart agriculture? Current Opinion in Environmental Sustainability, 8, 39-43. https://doi.org/10.1016/j.cosust.2014.07.002.

Coates, J., \& Bilinsky, P. (2007). Household Food Insecurity Access Scale ( HFIAS ) for Measurement of Food Access : Indicator Guide VERSION 3 Household Food Insecurity Access Scale (HFIAS) for Measurement of Food Access : Indicator Guide VERSION 3, (August).

Coulthard, S., Johnson, D., \& McGregor, J. A. (2011). Poverty, sustainability and human wellbeing: A social wellbeing approach to the global fisheries crisis. Global Environmental Change, 21(2), 453-463. https://doi.org/10.1016/j.gloenvcha.2011.01.003.

Davis, B., Di Giuseppe, S., \& Zezza, A. (2017). Are African households (not) leaving agriculture? Patterns of households' income sources in rural Sub-Saharan Africa. Food Policy, 67, 153-174. https://doi.org/10.1016/j.foodpol.2016.09.018.

Dolan, P., Layard, R., \& Metcalfe, R. (2011). Measuring Subjective wellbeing for public policy. Office for National Statistics, (February), 19. https://doi.org/10.2752/174589311X12961584845846.

Douxchamps, S., Ayantunde, A., Panyan, E. K., \& Ouattara, K. (2015). Agricultural water management and livelihoods in the crop - livestock systems of the Volta Basin. Water Resources and Rural Development, 6, 92-104. https://doi.org/10.1016/j.wrr.2014.10.001.

EPA. (2015). Ghana's Third National Communication Report to the UNFCCC 2015 Climate Change Report Ghana's Third National Communication Report to the UNFCCC. Accra, Ghana. Retrieved from http://unfccc.int/resource/docs/natc/ghanc3.pdf.

FAO. (2013). Climate Smart Agriculture Sourcebook. Rome, Italy: Food and Agriculture Organization of the United Nations (FAO). Retrieved from http://www.fao.org/docrep/018/i3325e/i3325e.pdf.

Garrity, D. P., Akinnifesi, F. K., \& Ajayi, O. C. (1876). Evergreen Agriculture: A Robust Approach to Sustainable Food Security in Africa. Food Security, 2(3), 197-214. https://doi.org/10.1007/s12571-010-0070-7.

Giller, K. E., Witter, E., Corbeels, M., \& Tittonell, P. (2009). Conservation agriculture and smallholder farming in Africa: The heretics' view. Field Crops Research, 114(1), 23-34. https://doi.org/10.1016/j.fcr.2009.06.017.

GSS. (2014a). Ghana Living Standards Survey Round 6. Accra, Ghana. https://doi.org/10.1007/s13398-014-0173-7.2.

GSS. (2014b). 2010 Pupolation and Census Report: Bongo District Analytical Report. Accra, Ghana.

Johansen, C., Haque, M. E., Bell, R. W., Thierfelder, C., \& Esdaile, R. J. (2012). Conservation agriculture for small holder rainfed farming: Opportunities and constraints of new mechanized seeding systems. Field Crops Research, 132, 18-32. https://doi.org/10.1016/j.fcr.2011.11.026.

Latham, B. (2007). Sampling: What is it? Quantitative Research Methods.

Lolig, V., Donkoh, S. A., Obeng, F. K., Gershon, I., Ansah, K., Jasaw, G. S., ... Kranjac-berisavljevic, G. (2014). Households ' Coping Strategies in Drought- and Flood-Prone Communities in Northern Ghana. Journal of 
Disaster Research, 9(4).Long, T. B., Blok, V., \& Coninx, I. (2016). Barriers to the adoption and diffusion of technological innovations for climate-smart agriculture in Europe: Evidence from the Netherlands, France, Switzerland and Italy. Journal of Cleaner Production, 112, 9-21. https://doi.org/10.1016/j.jclepro.2015.06.044.

Lowder, S. K., Skoet, J., \& Singh, S. (2014). What do we really know about the number and distribution of farms and family farms in the world? Background Paper for the State of Food and Agriculture 2014 (ESA Working Paper No. 14-02). Rome. Retrieved from www.fao.org/economic/esa.

Makate, C., Wang, R., Makate, M., \& Mango, N. (2016). Crop diversification and livelihoods of smallholder farmers in Zimbabwe: adaptive management for environmental change. SpringerPlus, 5(1), 1135. https://doi.org/10.1186/s40064-016-2802-4.

Mawunya, F. D., \& Adiku, S. G. . (2013). Climate Change in Ghana: Impacts on Agriculture and the Policy Implications. Ghana Policy Journal, 5.

Megersa, B., Markemann, A., Angassa, A., \& Zárate, A. V. (2014). The role of livestock diversification in ensuring household food security under a changing climate in Borana , Ethiopia. Food Security, 6, 15-28. https://doi.org/10.1007/s12571-013-0314-4.

Nyantakyi-Frimpong, H., \& Bezner-Kerr, R. (2015). The relative importance of climate change in the context of multiple stressors in semi-arid Ghana. Global Environmental Change, 32, 40-56. https://doi.org/10.1016/j.gloenvcha.2015.03.003.

Nyantakyi-Frimpong, H., \& Bezner Kerr, R. (2015). A political ecology of high-input agriculture in northern Ghana, 34(1), 13-35.

Peterson, C. (2014). Local-level appraisal of benefits and barriers affecting adoption of climate-smart agricultural practices: Ghana. Copenhagen, Denmark.

Peterson, C. A. (2014). Local-level appraisal of benefits and barriers affecting adoption of climate-smart agricultural practices: Ghana. Copenhagen, Denmark: CGIAR Research Program on Climate Change, Agriculture and Food Security (CCAFS).

Rademacher-schulz, C., Schraven, B., \& Mahama, E. S. (2014). Time matters : shifting seasonal migration in Northern Ghana in response to rainfall variability and food insecurity. Climate and Development, 6(1), 4652. https://doi.org/10.1080/17565529.2013.830955.

Riede, J. O., Posada, R., Fink, A. H., \& Kaspar, F. (2016). Adaptation to Climate Change and Variability in Rural West Africa, 7-24. https://doi.org/10.1007/978-3-319-31499-0.

Scherr, S. J., Shames, S., \& Friedman, R. (2012). From climate-smart agriculture to climate-smart landscapes. Agriculture \& Food Security, 1(1), 12. https://doi.org/10.1186/2048-7010-1-12.

Stringer, L. C., Dyer, J. C., Reed, M. S., Dougill, A. J., Twyman, C., \& Mkwambisi, D. (2009). Adaptations to climate change, drought and desertification : local insights to enhance policy in southern Africa, 12, 748765. https://doi.org/10.1016/j.envsci.2009.04.002.

Tambo, J. A., \& Wünscher, T. (2017). Farmer-led innovations and rural household welfare: Evidence from Ghana. Journal of Rural Studies, 55, 263-274. https://doi.org/10.1016/j.jrurstud.2017.08.018.

Tay, L., \& Diener, E. (2011). Needs and subjective well-being around the world. Journal of Personality and Social Psychology, 101(2), 354-365. https://doi.org/10.1037/a0023779.

Tilman, D., Balzer, C., Hill, J., \& Befort, B. L. (2011). Global food demand and the sustainable intensification of agriculture. Proceedings of the National Academy of Sciences of the United States of America, 108(50), 20260-4. https://doi.org/10.1073/pnas.1116437108.

Valbuena, D., Tui, S. H. K., Erenstein, O., Teufel, N., Duncan, A., Abdoulaye, T., ... Gérard, B. (2014). Identifying determinants, pressures and trade-offs of crop residue use in mixed smallholder farms in Sub-Saharan Africa and South Asia. Agricultural Systems. https://doi.org/10.1016/j.agsy.2014.05.013.

Van Der Geest, K. (2011). North-South Migration in Ghana: What Role for the Environment?, 49. https://doi.org/10.1111/j.1468-2435.2010.00645.x.

WFP. (2008). Technical Guidance Sheet-Food Consumption Analysis: Calculation and use of food consumption in food security analysis. Rome, Italy. Retrieved from http://documents.wfp.org/stellent/groups/public/documents/manual_guide_proced/wfp197216.pdf. 
Yaro, J. A. (2013). Building Resilience and Reducing Vulnerability to Climate Change: Implications for Food Security in Ghana, (August 2013), 14. Retrieved from http://www.fesghana.org/uploads/PDF/FES_ResilienceVulnerability_CC_Ghana_2013_FINAL.pdf.

Zougmoré, R., Partey, S., Ouédraogo, M., Omitoyin, B., Thomas, T., Ayantunde, A., ... Jalloh, A. (2016). Toward climate-smart agriculture in West Africa: a review of climate change impacts, adaptation strategies and policy developments for the livestock, fishery and crop production sectors. Agriculture \& Food Security, 5(1), 26. https://doi.org/10.1186/s40066-016-0075-3.

\section{Copyrights}

Copyright for this article is retained by the author(s), with first publication rights granted to the journal.

This is an open-access article distributed under the terms and conditions of the Creative Commons Attribution license (http://creativecommons.org/licenses/by/4.0/). 